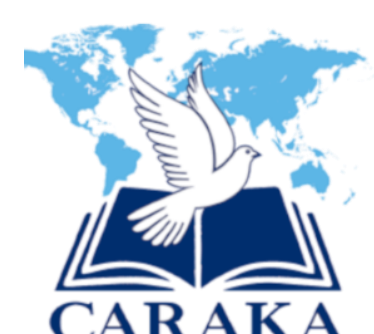

\begin{tabular}{|l|l|l|} 
Diserahkan: 04 Juli 2020 & Diterima: 17 Agustus 2020 & Diterbitkan: 28 September 2020 \\
\hline
\end{tabular}

\title{
EKOTEOLOGI : TINJAUAN TEOLOGI TERHADAP KESELAMATAN LINGKUNGAN HIDUP
}

\author{
Marthinus Ngabalin, S. Th., M. Si \\ STT Gereja Protestan Indonesia di Papua-Fakfak \\ marthinusngabalin@sttgpipapua.ac.id
}

\begin{abstract}
The world created by God, with everything in it is saved as an expression of God's justice that should be guarded to maintain a cosmological balance for the welfare of all beings. However, it is realized, that human individualism often control itself to exploit nature. It is realized that the conception of salvation possessed by the Church had long been dominated by humancentered theology of salvation, consciously putting aside the conscience of life and salvation which are also the right of all beings. This research is a qualitative research with a literature study approach. This study aims to explain the ecotheology of the environment, its model and its implementation as a human effort in overcoming natural and environmental problems.
\end{abstract}

Keywords: Nature; life; salvation; ecotheology

\begin{abstract}
Abstrak
Dunia yang diciptakan oleh Allah, dengan segala sesuatu yang mendiaminya diselamatkan sebagai wujud keadilan Allah yang patut dikawal untuk menjaga keseimbangan kosmologi bagi kesejahteraan segala makhluk. Namun di dalam kenyatannya, sikap individualisme manusia seringkali menguasai dirinya untuk mengeksploitasi alam. Disadari bahwa konsep keselamatan yang dimiliki oleh Gereja sudah sejak lama didominasi oleh teologi keselamatan yang bersifat berpusat pada manusia, yang secara sadar mengesampingkan nurani kehidupan dan keselamatan yang juga adalah hak segala makhluk. Penelitian merupakan penelitian kualitatif dengan pendekatan studi pustaka. Penelitian ini memiliki tujuan untuk menjelaskan ekoteologi lingkungan hidup, model serta implementasinya sebagai upaya manusia dalam mengatasi masalah alam dan lingkungan hidup.
\end{abstract}

Kata Kunci: Alam; Kehidupan; Keselamatan, Ekoteologi 


\section{PENDAHULUAN}

Fenomena kerusakan lingkungan hidup menjadi isu dunia saat ini. Kerusakan alam, eksploitasi laut dan pembuangan sampah secara sembarangan menjadi hal yang sangat menarik dalam kehidupan saat ini. Manusia dituntut untuk turut menyelamatkan lingkungan, dari orang-orang yang tidak menjaga keselamatan lingkungan. Sikap nir etik atau tanpa etika terhadap alam dalam bentuk eksploitasi, manipulasi dan dominasi yang overdosis terhadap alam merupakan arogansi manusia yang terlampau berlebihan. Alam seakan tanpa nilai apapun dihadapan manusia, kecuali sebagai instrument bagi pemenuhan kebutuhan hidup manusia semata. ${ }^{1}$ Sikap manusia seperti ini telah menyebabkan manusia harus menerima reaksi dari alam yang hancur, seperti bencana alam, pembuangan sampah secara sembarangan, tanah longsor, krisis air, dan sebagainya.

Data Kementerian lingkungan hidup dan kehutanan, Indonesia memproduksi sampah hingga 65 juta pada 2016, dan meningkat menjadi 67 ton pada tahun 2017. Sementara itu, adat Pusat Oceanografi LIPI menunjukkan, sekitar 33,15\% terumbu karang di Indonesia dalam kondisi tidak baik dan hanya 6,39 \% dalam kondisi yang sangat baik. Pemanasan global dipicu karena pembakaran batu bara yang mencapai jumlah emisinya per tahun yaitu 9 miliar ton Co2; adanya konversi lahan dan perusakan hutan dengan jumlah emisi mencapai 2,53 miliar ton Co2e; dan aktifitas pemakaian energy, pertanian dan limbah dengan 451 juta Co2. Permasalahan lain yang menjadi persoalan lingkungan adalah pemanasan global, yakni proses meningkatnya suhu rata-rata atmosfer laut dan permukaan bumi. Banyak dampak yang ditimbulkan dari pemanasan global seperti rusaknya ekosistem makhluk hidup dan tenggelamnya pulau-pulau kecil, karena naiknya permukaan air laut akibat mencairnya lapisan es di kutub. ${ }^{2}$

Terhadap permasalahan dimaksud, maka Gereja tetapi juga para teolog diharapkan untuk dapat menopang pemerintah dalam rangka menyelamatkan lingkungan hidup. Teologi lingkungan hidup ini dimaksudkan untuk mendudukan proporsi keselamatan Allah yang bersifat universal bagi dunia seutuhnya; menggugah manusia, dan atau orang Kristen untuk membangun paradigma pengabdian yang lebih komprehensif bagi sesama dan alam ciptaan Tuhan secara utuh. Teologi lingkungan hidup ini diharapkan dapat diimplementasikan dalam aksi-aksi sebagai bentuk dan karakter berteologi secara kontekstual.

\footnotetext{
${ }^{1}$ Budi Widianarko, Membumikan Etika Lingkungan (Yogyakarta: Kanisius, 2011), 78.

${ }^{2}$ Datuak Tjumano, "Kerusakan Lingkungan Hidup Di Indonesia | Jurnal Intelijen," https://jurnalintelijen.net/2018/07/03/kerusakan-lingkungan-hidup-di-indonesia/. 


\section{METODE PENELITIAN}

Metode yang digunakan dalam penulisan ini adalah metode kualitatif. Penelitian kualitatif sendiri pada hakekatnya ialah mengamati orang dalam lingkungan bahasa dan tafsiran mereka tentang dunia sekitarnya. ${ }^{3}$ Data dikumpulkan dengan menggunakan bukubuku yang membahas dan menyoroti tentang fokus penulisan. Pendekatan yang digunakan dalam penelitian ini adalah studi pustaka yang merupakan teknik pengumpulan data dengan cara studi terhadap sumber literatur yang berhubungan dengan masalah yang di bahas. ${ }^{4}$

\section{HASIL DAN PEMBAHASAN}

\section{Ekoteologi Lingkungan Hidup}

Hubungan antara manusia dengan alam juga menjadi tidak harmonis. Semua itu disebabkan oleh ketidakberdayaan dan atau ketidak-mampuan manusia dalam mengorganisir kepentingan/kebutuhannya secara baik. Egoisme manusia yang meledak-ledak dan tak terkendali terbungkus rapi dalam sebuah kemasan pemahaman, bahwa alam diciptakan oleh Allah untuk kepentingan manusia semata. Manusia tidak pernah mempertanyakan "apakah ada kepentingan Allah menciptakan dan menjadikan manusia untuk kepentingan dan atau kebutuhan alam semesta?"

Bahasa Oikumene yang didengungkan oleh manusia, dipahami hanya sebatas hubungan manusia dengan manusia, itu pun dalam hubungan antar denominasi antar gereja. Hubungan antara manusia dengan orang lain di luar Gereja, apalagi dengan alam atau makhluk ciptaan yang lain, sering dipahami berada di luar pengertian oikumene itu sendiri. Padahal oikumene dalam pengertian harafiahnya adalah dunia yang didiami. Pertanyaan yang dapat penulis kemukakan lagi ialah siapakah atau apakah yang lebih berhak dan layak mendiami ruang dunia ini. Manusia dan segala makhluk berhak dan layak menempati/ mendiami dunia ini, dan cara mendiami dunia inipun sama dalam satu ekosistem yang saling menghidupi dan melengkapi.

Strata manusia yang melebihi segala makhluk ciptaan Allah yang lain, pada kenyataannya telah salah di interpretasi oleh manusia, yang memahami dirinya sebagai penguasa mutlak bagi seluruh alam semesta. Tidak heran, jika manusia tetap memperlihatkan sikapnya yang arogan terhadap alam. Tanpa rasa penghargaan yang layak bagi alam dengan esensinya, manusia memanipulasi alam dengan dasar teologi yang bersifat antroposentris. Segala sesuatu yang ada di alam ini hanya untuk kepentingan manusia. Ini merupakan sebuah kenaifan yang harus ditobatkan dalam pikiran manusia yang beragama.

\footnotetext{
${ }^{3}$ S Nasution, Metode Penelitian Naturalistik Kualitatif (Bandung: Tarsito, 1996), 78.

4 Dicky Dominggus, "Pengabdian Abdi Dalem Keraton Yogyakarta Sebagai Potret Pelayanan Masa Kini," Voice of Hami 2, no. 2 (2020): 89. 
Krisis lingkungan hidup yang dihadapi umat manusia dewasa ini merupakan akibat langsung dari pengelolaan lingkungan hidup yang tidak didasarkan pada kesadaran etika, moral dan spiritual religius yang tertanggung jawab. Dengan kata lain, krisis ekologi yang dihadapi umat manusia sebetulnya berakar dalam krisis etika, krisis moral dan krisis spiritual religius manusia. Kesadaran akan adanya kehidupan manusia yang juga dimungkinkan oleh ketersediaan sumbersumber daya alam ciptaan Tuhan, pada kenyataannya telah terkikis habis oleh egoisme manusia yang tanpa hati nurani mengeruk dan atau menggarap alam lingkungan. Manusia telah melakukan ketidakadilan yang sangat memojokkan eksistensi dirinya secara tanpa sadar, bahwa manusia dijadikan atau diciptakan untuk bertanggung jawab (berlaku adil) terhadap alam ciptaan Allah yang lainnya. Sebuah tanggung jawab perjuangan untuk keselamatan semesta, sejak mulanya telah dianugerahkan kepada manusia oleh sang khalik. ${ }^{5}$

Melalui alam, Allah menyediakan kepada manusia apa yang menjadi kebutuhan manusia untuk bisa dinikmati, namun ketika manusia puas mengambil apa yang ada di alam, manusia juga telah merampas apa yang mestinya menjadi milik esensial pada alam itu sendiri, yakni kehidupan. Manusia harus menyadari, bahwa tidak ada kepuasan final yang akan dialami olehnya ketika manusia mengambil segala sesuatu yang dimiliki oleh alam ini, kecuali manusia sendiri sadar, bahwa kepuasan akan dinikmati jika ia memberi kesempatan juga kepada alam untuk menikmati apa yang ada pada dirinya (alam) itu sendiri. Tidak ada manusia yang puas ketika melihat alam mengalami kegersangan, bahkan sebaliknya, manusia turut mengalami kegersangan batin dan kehampaan hidup ketika seluruh tatapannya tertuju pada alam yang gersang dan potensial mati. Mungkin hal ini tidak begitu menggugah manusia, padahal manusia sendiri mengalami dan menikmati akibat langsung dari sebuah kegersangan dan atau kerusakan lingkungan.

\section{Model Ekoteologi Lingkungan Hidup}

Ada beberapa aspek yang dapat di gagas dalam membangun Teologi lingkungan hidup berdasarkan acuan ranah teologi kontekstual ${ }^{6}$ :

\section{Konsep Tentang Allah Dalam Teologi Lingkungan Hidup}

Allah yang digambarkan dalam teologi lingkungan hidup adalah Allah sebagai: pencipta, pemelihara dan penyelamat dunia. Sebagai pencipta, Allah dipahami sebagai causa prima (sebab yang utama), zat yang menjadikan dunia (manusia dan segala makhluk yang lain). Pernyataan pertama dari pengakuan iman rasuli dan pengakuan iman Nicea Konstantinopel adalah pengakuan tentang Allah sebagai pencipta langit dan bumi atau alam semesta. Secara khusus dalam

\footnotetext{
${ }^{5}$ Widianarko, Membumikan Etika Lingkungan, 79.

${ }^{6}$ Dave J Rupilu, “Teologi Alam Semesta,” Jurnal Ilmiah Tangkoreh Putai 3, no. 1 (2007): 72. 121 | Copyright $@$ 2020, CARAKA, ISSN 2722-1407 (Cetak), 2722-1393 (Online)
} 
pengakuan iman Nicea Konstantinopel berbunyi "Aku percaya kepada satu Allah, bapa yang maha kuasa, pencipta langit dan bumi, segala yang kelihatan dan yang tidak kelihatan". Penggunaan istilah "yang kelihatan dan yang tidak kelihatan", menunjukan bahwa Allah menciptakan segala sesuatu tanpa kecuali. ${ }^{7}$

Pengakuan Iman sebenarnya tidak berbicara tentang terjadinya alam semesta, tetapi berbicara tentang Allah Bapa sebagai khalik. Cerita Alkitab tentang penciptaan, tidak menjelaskan kepada kita cara terjadinya dunia, kehidupan dan manusia. Cerita itu mau menjadi suatu nyanyian pujian, pemberitaan dan khotbah tentang Allah. ${ }^{8}$ Di dalam ajaran Gereja Kristen, persoalan bukan terletak pada terjadinya dunia yang menjadi daya tarik dan perhatian kita, tetapi hubungan antara dunia kita dengan Allah yang telah menyatakan diri-Nya di dalam kedatangan Yesus Kristus. Alkitab, gereja dan ilmu-ilmu teologi hendak menyampaikan kepada kita dan dunia ini jawaban yang aktual atas pertanyaan bagaimana sikap Allah terhadap dunia kita dan bagaimana seharusnya jawaban kita atas hubungan yang telah diadakan Allah sendiri dengan dunia dan manusia. ${ }^{9}$

Sikap yang mesti ditonjolkan oleh manusia terhadap Allah Sang Pencipta adalah ketergantungan karena percaya yang sungguh-sungguh kepada Allah yang menyediakan bagi manusia segala sesuatu yang menjadi isi dari alam semesta ini. Hubungan manusia dengan Allah, selalu menjadi persoalan pelik yang digumuli dalam wacana-wacana berteologi. Konsep tentang kehadiran dan keterlibatan Allah dalam dunia ciptaannya, menggiring manusia percaya untuk memahami bahwa hubungan yang damai dan fungsional dengan sesama yang membutuhkan. Peran apostolis manusia dan hubungan yang asri dengan alam semesta di mana Allah berdaulat dapat dipahami bahwa itu merupakan realitas hubungan yang dibangun oleh manusia dengan Allah sebagai pencipta.

Allah sebagai pemelihara, menggambarkan konsistcnsi Allah sebagai yang berdaulat dan penuh cinta kasih terhadap seluruh buatan tangan-Nya. Kasih pemeliharaan Allah ditujukan kepada dunia seutuhnya, bukan hanya manusia, tetapi alam semesta ini. Sebagai milik yang di kasihi, maka manusia dan seisi alam semesta dijaga, dipelihara, ditebus dan disclamatkan Allah. "Karena begitu besar kasih Allah akan dunia ini...." (Yohanes 3 : 16). Kata dunia ini menggambarkan totalitas semesta berhak untuk menikmati kasih Allah. Manusia tidak berhak untuk mengklaim kasih Allah itu menjadi milik pribadi atau kelompok, dan atau spesiesnya sendiri. Kasih Allah kepada seluruh ciptaanNya dinyatakan bukan hanya dalam arti memelihara

\footnotetext{
${ }^{7}$ Ebenhaizer Nuban Timo, Allah Menahan Diri, tetapi Pantang Berdiam Diri: Suatu Upaya Berdogmatika Kontekstual Di Indonesia (Jakarta: BPK Gunung Mulia, 2015), 72.

${ }^{8}$ G C Van Niftrik and B J Bolland, Dogmatika Masa Kini (Jakarta: BPK Gunung Mulia, 1981), 113.

${ }^{9}$ Ibid, 115.
} 
ciptaan itu selaku miliknya, tetapi juga dengan mengikutsertakan seluruh ciptaan dalam kerangka perjanjian dan penebusan yang dilakukan Allah terhadap seluruh ciptaannya. ${ }^{10}$

Pengaruh pandangan dualisme, yang memahami alam bukan bersifat ilahi, tetapi alam juga tidak bersifat buruk juga nampak dalam pandangan para reformator, misalnya dalam pandangan dualisme keselamatan yang memandang keselamatan sebagai karya dari penebusan Kristus hanya ditujukan kepada manusia, sedangkan alam dan obyek material lainnya tidak mengambil bagian dalam keselamatan dari penebusan Kristus. Menurut Luther, alam bukanlah sesuatu yang manusia cari untuk bcrsekutu dengannya. Alam bukan saksi kemuliaan Allah. Sedangkan perhatian Calvin lebih dipusatkan pada hubungan manusia dengan Allah, sedangkan alam menjadi tambahan saja dan menjadi latar belakang dari drama penyelamatan manusia. $^{11}$

Pandangan kedua reformator ini sangat bersifat antroposentris, sebab walaupun mereka tidal lagi memandang alam sebagai sesuatu yang jelek/buruk, namun masih cenderung meremehkan dunia atau alam bendawi. Pandangan antroposentik ini menyebabkan manusia hanya memikirkan spesiesnya dalam hubungan dengan Tuhan. Manusia cenderung memandang sesuatu yang bermakna hanya dalam konteks hubungan sosial. Memang pandangan gereja cukup dominan bertolak dari Alkitab selalu berpegang teguh pada keyakinan, bahwa Allah pencipta adalah Allah penebus, tetapi penebusan hanya terkait dengan manusia. Itulah ciri teologi yang bersifat antroposentrik.

Allah sebagai penebus, memperlihatkan eksistensi keterlibatannya dalam mengubah dan mengembalikan hidup manusia, dan juga alam yang rusak, kehilangan daya vitalitas berinteraksi antara manusia dengan Allah yang sekaligus pula dinampakkan dalam relasi yang harmonis dengan alam dalam kesatuan ekosistem di planet bumi. "Ekosistem adalah tata penciptaan sekaligus tata pemeliharaan dan penebusan Allah atas alam semesta. Apa yang disebut hukum-hukum alam adalah peraturan-peraturan Allah tentang ciptaan". ${ }^{12}$ Seluruh ciptaan memuji Allah dalam proses perkembangan dan pertumbuhannya sesuai dengan aturan kekal yang ditetapkan oleh Allah dalam tata ciptaan (Mazmur 148 : 1-3).

Ditegaskan, bahwa tindakan penebusan Allah yang nyata dalam seluruh eksistensi Kristus ditujukan kepada seluruh makhluk yang ada di alam semesta. Tindakan penebusan Allah melalui pengorbanan Kristus menekankan tentang kepedulian Allah kepada seluruh ciptaanNya, baik dengan manusia maupun dengan ciptaan yang lain adalah bersifat holistik. Seluruh ciptaan berada dalam hubungan yang harmonis dan berpusat pada Allah. Alam adalah ciptaan Allah yang baik, dikuduskan dalam penebusan Kristus dan berada dalam pengawasan dan

\footnotetext{
${ }^{10}$ Robert P Borong, Etika Bumi Baru (Jakarta: BPK Gunung Mulia, 2000), 201.

11 Ibid, 186.

12 Ibid, 194.
} 
pemeliharaan Allah. Untuk memperlihatkan secara rinci sifat pemeliharaan Allah bagi segala makhluk, Alkitab menunjukkan bahwa tidak ada sesekor burung pipitpun yang jatuh ke bumi diluar kehendak Bapa di sorga (Matius 10:29). Bahwa Bapa di sorga memelihara burungburung yang tidak menabur, tidak menuai dan tidak menyimpan makanan (Matius 6:25-34).

Visi Mesianik yang ditonjolkan dari teks-teks Alkitab di atas menunjukan visi pemulihan dan sekaligus keselamatan universal keutuhan seluruh ciptaan milik Allah dalam ketergantungan dan keharmonisan yang benar. Alam dan manusia, dan manusia dengan manusia yang lain memiliki visi yang sama, karena menerima janji yang sama untuk dibarui, ditebus dan diperdamaikan oleh Allah dengan diriNya sendiri sebagai pencipta dan pemilik alam semesta. Konsekuensi dari keyakinan ini menjelaskan kedudukan alam dihadapan manusia, yaitu bahwa alam adalah milik Allah yang terikat dalam perjanjian pemulihan, pembaruan, dan penebusan yang dilakukan oleh Allah sendiri. Kedudukan alam yang sejajar dengan manusia sebagai sama-sama milik Allah, namun dengan fungsi yang berbeda, sehingga manusia bertanggung jawab menjaga dan memelihara alam ini menuju pemenuhan janji Allah yang sempurna dalam langit dan bumi baru.

Keterbukaan untuk memahami kesederajatan manusia secara universal dalam realitas penciptaan, pemeliharaan dan penebusan Allah harus memperoleh tempat dan atau porsi yang layak dari seluruh kepedulian manusia. Konsep ekklesia nula salus yang dibangun sebagai tembok tegar yang memagari semua orang Kristen pada zaman lampau, harus terbuka untuk dikritisi (dikoreksi dan dibaharui). Solusinya ialah konsep ekklesiologi harus digagas ulang, sehingga terminologi gereja tidak hanya terbatas pada teritori struktur atau lembaga gereja, melainkan dunia seutuhnya, dimana ada damai Allah, keadilan, kemanusiaan, kchidupan dan keselamatan universal. Gereja adalah para pejuang keadilan, kebenaran, kehidupan dan keselamatan universal yang ditaklukkan di bawah kedaulatan atau kekuasaan Allah.

Paul Knitter dan John Hick berpendapat bahwa, pada satu pihak, kebutuhan yang urgen untuk kesatuan manusia, dan pada pihak lain keyakinan bahwa satu tradisi keagamaan yang khusus tidak dapat memberikan fokus kesatuan itu, termasuk klaim-klaim Kristen akan keunikannya juga harus ditolak. Pendapat yang senada juga dikemukakan oleh teolog India Stanley Samartha, yang menyebutkan bahwa situasi kita pada masa kini sangat berbeda dalam segala hal di dalam sejarah manusia, dalam hal ini kita menghadapi kehancuran total dari semua kehidupan oleh polusi lingkungan atau oleh malapetaka nuklir, karena itu merupakan ancaman terhadap seluruh kemanusiaan, maka untuk mengklaim bahwa satu tradisi keagamaan mempunyai satu-satunya jawaban untuk persoalan global seperti itu rasanya tidak masuk 
akal. ${ }^{13}$ Itu berarti siapapun dan dimanapun gereja dapat menunjukan peran apostolisnya (kenabiannya) unluk keselamatan semesta.

\section{Konsep Manusia dalam Teologi lingkungan hidup}

Dalam perspektif Teologi lingkungan hidup, manusia adalah sebagai citra dan mitra Allah bagi dan dalam dunia seutuhnya. Manusia memiliki tanggung jawab moral dalam menjaga kelestarian lingkungan sekitarnya. ${ }^{14}$ Perspektif ini mengindikasikan kehadiran dan keberadaan manusia yang turut bergumul mengaplikasikan pengakuan dan kehadiran Allah yang mencipta, memelihara dan menebus seluruh karya-Nya.

Kehadiran manusia di tengah-tengah dunia mengindikasikan kehadiran Allah yang terus berkarya. Konsep ini mengingatkan manusia untuk berperan secara bertanggung jawab, karena seluruh perannya menampilkan peran Allah. Manusia merupakan citra Allah berarti manusia bertanggung jawab pula dalam menghadirkan wajah dan karakter Allah yang memelihara segala ciptaanNya. Jika manusia tidak memelihara tetapi semata-mata mau menguasai alam, maka ia menolak eksistensi dirinya sebagai citra Allah. Dalam istilah representasi Allah, tidak tepat dan terkesan berlebihan, karena manusia memiliki keterbatasan, tetapi manusia harus memahami dirinya sebagai wakil atau mandataris Allah yang telah menciptakan alam semesta dan terus ada dalam karyaNya yang tidak terbatas dalam menjaga dan memelihara segala ciptaanNya. Peran penjagaan dan pemeliharaan Allah itu diwujudkan dalam keterlibatan secara sadar dan bertanggung jawab dari manusia terhadap seluruh ciptaan Allah.

Manusia sebagai mandataris Allah merupakan esensi dari seluruh panggilan apostolisnya ditengah-tengah dunia. Artinya, manusia turut bertanggung jawab terhadap dunia ciptaan Allah, sehingga dunia seutuhnya terlibat dalam tindakan cinta kasih dan keselamatan Allah sendiri. Peran aplikatif dari rasa keterpanggilan manusia, dan sekaligus menjawab amanat Allah Sang Khalik berwujud dalam aktifitas pemeliharaan alam oleh manusia secara sadar dan beretika. Manusia tidak mesti mendewakan dirinya ditengah dunia terhadap ciptaan Allah yang lainnya, apalagi mendewakan dirinya dihadapan sesama umat manusia.

Keangkuhan manusia yang memahami dirinya sebagai yang superior diantara makhluk ciptaan Allah yang lain. Pada kenyataannya, pemahaman ini telah menggiring manusia pada sentra dimana keselamatan dipahami sebagai anugerah yang hanya dikhususkan kepada manusia. Secara sadar manusia dalam keegoisannya telah terbangun karakter dan sikap yang tanpa menghargai alam sebagai bagian dari hidupnya. Alam hanya dijadikan sebagai instrumen pelengkap bagi pemenuhan kehidupan manusia. Pemahaman seperti ini justru sangat jauh dari realitas

\footnotetext{
${ }^{13}$ Lesslie Newbigin, Injil Dalam Masyarakat Majemuk (Jakarta: BPK Gunung Mulia, 2000), 219.

${ }^{14}$ Jefri Hina Remikatu, "Teologi Ekologi: Suatu Isu Etika Menuju Eskatologi Kristen," CARAKA: Jurnal Teologi Biblika dan Praktika 1, no. 1 (May 2020): 70 
kontekstual, bahwa manusia tidak bisa hidup tanpa alam, letapi alam bisa hidup tanpa manusia. Sangat disayangkan lagi, ketika manusia dengan sadar mengekploitasi, memanipulasi dan menelanjangi alam hanya untuk kepentingan diri manusia sendiri, dengan tidak merasa malu dan bersalah sedikitpun manusia merusak alam demi kepentingan eksperimen alat-alat industri ciptaan manusia sendiri. Sikap ini sekaligus memperlihatkan, kesalahan interpretasi terhadap kuasa yang diberikan oleh Allah kepada manusia. Bahwa kepada manusia telah diberi kuasa untuk menguasai dan memanfaatkan alam untuk kepentingannya, tetapi berbarengan dengan kuasa itu, ada pernyataan yang bernada perintah untuk memelihara. Artinya, bahwa penguasaan dan pemanfaatan alam bagi kepentingan manusia itu betul, tetapi yang lebih tepat adalah manusia harus menghargai alam sebagai subyek yang memiliki hakikat hidup sama seperti manusia sendiri.

Dalam Kejadian 1:11, 12,24, 26, dan 28 yang memberi ketegasan secara scripturalistik, bahwa manusia diserahi tanggung jawab penguasaan atas alam/bumi. Ada 3 penegasan yang dapat disimpulkan dari ayat-ayat Alkitab ini, yaitu: Pertama, Allah memberikan manusia kekuasaan atas bumi. Sejak awal, manusia sudah dikaruniai dengan suatu keunikan ganda, yakni sebagai gambar Allah (terdiri dari kualitas-kualitas rasional, moral, sosial dan spiritual yang memungkinkan manusia mengenal Allah), dan manusia memegang kekuasaan atas bumi dan segala makhluknya. Kekuasaan manusia yang unik atas bumi adalah hubungan kita yang unik dengan Allah. Kedua, kekuasaan atas bumi adalah suatu kekuasaan kooperatif. Artinya, dalam menjalankan pemberian Allah itu, manusia bukannya menciptakan, melainkan bekerja sama dengan proses-proses alamiah itu. Ketiga, pendominasian manusia adalah pemberian, karena itu suatu pendominasian yang bertanggung jawab. Artinya, manusia menguasai bumi, bukan berdasarkan hak manusia, melainkan berdasarkan perkenanan Allah. Bumi ini milik manusia, bukan karena manusia yang menciptakannya, melainkan karena pencipta-nya telah mempercayakan manajemennya kepada manusia. ${ }^{15}$

Kejatuhan manusia ke dalam dosa telah menyebabkan pula alam semesta dikutuk. Alam semesta telah menjadi suatu yang asing bagi manusia, yang penuh dengan misteri yang menakutkan. Hubungan yang ramah telah berubah menjadi hubungan yang menakutkan. Dalam agama-agama suku, hubungan manusia dengan alam digambarkan sebagai hubungan antar subyek, di mana subyek yang satunya adalah alam yang dapat menimbulkan bahaya bagi manusia apabila manusia tidak berhati-hati dengannya. Hubungan subyek obyek yang ditemui dalam dunia masyarakat modern, tidak ada di dalam alam pemikiran masyarakat tradisional yang menganut kepercayaan suku. ${ }^{16}$ Dalam masyarakat modern, di mana teknologi memainkan peranan penting, alam semesta hanyalah semata-mata obyek yang misterinya mau diselidiki dan

\footnotetext{
${ }^{15}$ John Stott, Isu-Isu Global: Menantang Kepemimpinan Kristen (Jakarta: Yayasan Bina Kasih OMF, 1984), 150.

${ }^{16}$ A G Honig Jr, Ilmu Agama I (Jakarta: BPK Gunung Mulia, 1966), 16.

126 | Copyright $@$ 2020, CARAKA, ISSN 2722-1407 (Cetak), 2722-1393 (Online)
} 
dibukakan. Hubungan yang ramah dengan alam semesta telah berubah menjadi hubungan yang mengeksploitir, mendominasi dan memanipulasi demi kepentingan manusia sendiri. Alam semesta dipandang sebagai obyek yang diletakkan dibawah kekuasaan manusia. ${ }^{17}$

Secara eksistensial, manusia ditempatkan oleh Allah Sang Khalik didalam hubungan dengan alam sedemikian rupa, sehingga : (a) eksistensi manusia adalah eksistensi di dalam alam, karena itu manusia berada dan terikat didalam kehidupan alami sebagai suatu kesatuan kehidupan, dan konsekwensinya adalah bahwa manusia menjalani hidupnya dan merealisasikan eksistensinya di dalam alam, didalam ikatan kesatuan kehidupan alami. (b) eksistensi manusia adalah eksistensi di atas alam, sebagai yang menguasai alam, dan harus mengolah alam untuk menunjang kehidupannya. Dengan kata lain, alam menjadi sarana bagi manusia untuk menjalani hidupnya. Konsekswensinya adalah manusia harus mengolah alam sedemikian rupa, sehingga alam tetap terjalin didalam dan mendukung realisasi eksistensi manusia. Dengan kata lain, manusia harus bersikap manusiawi terhadap alam. "Situasi eksistensial cultural yang didalamnya oleh Tuhan manusia ditempatkan, mengimplementasikan sekaligus keharusan bagi manusia untuk memelihara alam sebagai kesatuan kehidupan alami dan untuk menguasai alam dan mengolahnya untuk menunjang kehidupannya". ${ }^{18}$

\section{Universalitas Eksistensi Manusia}

Semua orang sama di hadapan Allah, merupakan pernyataan yang tidak kalah gaungnya dengan narasi-narasi keadilan yang digemakan oleh kaum humaniora dalam konteks sosial dan budaya masyarakat di dunia ini. Pernyatataan ini semakin tertantang ketika memasuki area konsep keberagamaan yang eksklusif dan inklusif agama, yang menposisikan konsep keselamatan sebagai tujuan setiap individu atau kelompok umat beragama tertentu. Orang-orang Kristen juga menganut paham soteriologi ekklesia nula salus, dimana terletak kekuatan ekslusivisme gereja yang mengklaim keselamatan sebagai milik gereja atau orang Kristen. Tidak ada cara dan tempat lain yang memungkinkan adanya keselamatan, kecuali masuk dan menjadi bagian dan gereja atau menjadi Kristen. Klaim kebenaran seperti ini, hemat saya, didasarkan pada kesalahan interpretasi terhadap teks-teks Alkitab.

"Akulah jalan, kebenaran dan hidup" (Yohanes 14:6). Ayat ini dipakai sebagai senjata pemungkas untuk membenarkan diri sebagai orang Kristen yang menerima dan mengaku percaya kepada Yesus sebagai Juruslamat. Persoalan yang patut digumuli disini adalah apakah Yesus hanya milik orang Kristen? apakah klaim milik dan percaya kepada Yesus dalam label

\footnotetext{
${ }^{17}$ Nurasyah Dewi Napitupulu et al., "Ecotheology Dan Ecopedagogy: Upaya Mitigasi Terhadap Eksploitasi Alam Semesta,” Voice of Wesley: Jurnal Ilmiah Musik dan Agama 1, no. 2 (2018): 6.

${ }^{18}$ Andreas A Yewangoe, Pendamaian: Suatu Studi Tentang Pemulihan Relasi Antara Allah, Manusia Dan Alam Semesta (Jakarta: BPK Gunung Mulia, 1983), 182. 
Kristen seperti ini dapat menjadi dasar dan atau alasan untuk menyatakan kepada semua orang bahwa Yesus adalah orang Kristen atau Yesus hanya milik orang Kristen? Tidak ada manfaat yang lebih besar bagi orang Kristen jika Yesus dipahami hanya sebagai milik orang Kristen, sebab seluruh eksistensi dan identitas Yesus sebagai 'jalan, kebenaran dan hidup' ditujukan kepada dunia seutuhnya, bukan hanya kepada orang Kristen. Sebab Yesus sendiri tidak pernah menyatakan dirinya sebagai pendiri agama Kristen. Dia tetap sebagai orang Yahudi, yang sangat mengilhami karakter keyahudianNya, dan yang kemudian menterjemahkan atau mengaplikasikan karakter keyahudianNya dalam bentuk dan cara yang berbeda dan sangat baru, sehingga bukan hanya orang Yahudi tetapi seluruh umat manusia dan dunia ciptaan Allah lainnya tercerahkan oleh seluruh identitas dan karakter Yesus. ${ }^{19}$ Inkarnasi Allah dalam diri Yesus yang rela menjadi manusia, tidak ditujukan kepada sekelompok manusia yang bernama atau berlabel Kristen, melainkan seluruh umat manusia. Hal ini dimaksudkan untuk memungkinkan pengenalan dan penghayatan yang benar tentang Allah maha pencipta, pemelihara dan penebus seluruh umat manusia, dan alam semesta.

Konsep tentang kesamaan manusia harus bertolak dari Kristus yang antropomorfis dan atau imanen (Kristus yang menjadi manusia dan menyejarah). Banyak hal dapat membedakan individu yang satu dengan individu yang lain, atau kelompok manusia yang satu dengan kelompok manusia yang lain berdasarkan identitas kebudayaan, latar belakang sosial, ekonomi dan agama. Secara universal manusia, baik individu ataupun kelompok memiliki satu kesamaan jika individu atau kelompok itu dilekatkan pada esensi kemanusiaannya yang universal. Ada hakhak dan kewajiban-kewajiban yang melekat dan menjadi identitas bagi seluruh umat manusia.. Kesamaan itulah yang sering diakui sebagai hak asasi manusia, atas dasar pemahaman bahwa hak asasi manusia merupakan hak-hak universal dan kodrati yang mutlak diberikan oleh Tuhan kepada semua orang. Olaf Schumann berpendapat, bahwa hak asasi manusia merupakan hakhak yang berkaitan dengan hakikat, martabat manusia, dan karena itu tidak bisa dicabut. ${ }^{20}$ Tidak ada pihak apapun yang memberikan hak-hak itu, kecuali bagi orang-orang beragama Allah-lah pemberi dan sumber hak-hak itu. Filsafat pencerahan, karena ia mau netral dalam soal keagamaan, menempatkan hak-hak itu dalam tabiat-tabiat manusia, sebagai natural law yang ada diseberang segala usaha manusia untuk dapat menguasainya. Karena sifat dan hakikat manusia di mana-mana sama, maka hak-hak itupun dimana-mana sama adanya, dan karena itu disebut juga sebagai hak-hak yang universal. ${ }^{21}$

${ }^{19}$ Paul F Knitter, Satu Bumi Banyak Agama: Dialog Multi Agama Dan Tanggung Jawab Global (Jakarta: BPK Gunung Mulia, 2003), 16.

${ }^{20}$ Olaf Schumann, Menghadapi Tangangan Memperjuangkan Kerukunan (Jakarta: BPK Gunung Mulia, 2004), 25.

${ }^{21}$ Olaf Schumann, Peran Kristen Dalam Perjuangan Hak-Hak Sipil/Agama-Agama Dan Perjuangan Hak Sipil (Jakarta: Persekutuan Gereja Indonesia, 2002), 23.

128 | Copyright $@$ 2020, CARAKA, ISSN 2722-1407 (Cetak), 2722-1393 (Online) 


\section{Konsep Tentang Alam dalam Ekoteologi}

Alam tetap dipahami sebagai bagian dari totalitas ciptaan Allah yang dianggap dan atau dinilai baik olehNya pada saat penciptaan. Alam juga merupakan teritori utama yang dijadikan oleh Allah bagi segala makhluk yang lain, termasuk manusia. Karena alam adalah ciptaan Allah, maka alam mesti dipahami oleh manusia sebagai milik Allah, seperti manusia memahami dirinya sebagai milik Allah.

Mandat penguasaan alam yang diberikan kepada manusia, tetap menjadi bagian yang utuh dengan mandat pemeliharaannya. Kekuasaan dan kepemeliharaan alam yang diamanatkan atau diperintahkan oleh Allah kepada manusia merupakan dua sisi dari satu mata uang yang tidak bisa dilepaskan satu dari yang lainnya. Hal ini dimaksudkan untuk menghargai Allah sebagai pencipta, menghargai diri manusia sendiri sebagai citra dan mitra Allah, dan menghargai alam sebagai yang memiliki eksistensi kehidupan yang sama dengan manusia.

Perlakuan yang adil terhadap sesama manusia, mestinya diberlakukan pula pada alam. Dengan kata lain, keadilan sebagai moral lingkungan hidup harus teraplikasi dalam seluruh tanggung jawab penguasaan dan pemeliharaan alam. Keadilan sebagai moral lingkungan hidup, memberikan indikasi, bahwa lingkungan hidup memiliki hakikat yang esensial bagi dirinya sendiri untuk hidup, bertumbuh dan berkembang mengisi dunia selagi ia ada, hakikat yang esensial itu adalah hidup dan keadilan. ${ }^{22}$

Para ahli ekologi berpendapat bahwa gejala dan kenyataan krisis lingkungan hidup, sama sekali tidak terpisahkan dari praktek ketidakadilan manusia terhadap alam. Dengan kata lain, kerusakan lingkungan hidup, antara lain ditimbulkan oleh ketidakadilan manusia dalam mengelola lingkungan hidup. Gagasan seperti ini teristimewa disuarakan oleh teolog-teolog asal Amerika Latin, misalnya: Leonardo Boff, yang terus menghimbau manusia untuk bersikap baru terhadap bumi. Mitos tentang pertumbuhan alam tak terbatas harus ditolak. ${ }^{23}$ Selanjutnya para teolog Amerika Latin ini juga berpendapat, bahwa kita tidak bisa memahami ekologis secara akurat, bila dilepaskan dari ketidakadilan sosial manusia. Secara tidak sadar, penggarapan alam dan penggarapan terhadap hidup orang-orang miskin berjalan seiring dan bergandengan tangan. Pertama. ketidakadilan itu terkait dengan cara pandang dan perilaku manusia terhadap lingkungan hidup. Seandainya pandangan hidup manusia lebih mengutamakan kepentingan pribadi dan melalaikan kepentingan bersama dalam tata hidup sosial, ekonomi dan kebudayaan, bahwa tidak mustahil akan muncul ketidakadilan dalam pengelolaan lingkungan hidup; Kedua, penyalahgunaan dan penyelewengan terhadap norma-norma pengelolaan kekayaan alam, pasti menimbulkan ketidakadilan. Manusia menggunakan haknya secara berlebihan dengan menguras

\footnotetext{
${ }^{22}$ Rupilu, "Teologi Alam Semesta.", 38.

${ }^{23}$ William Chang, Moral Lingkungan Hidup (Jakarta: BPK Gunung Mulia, 2000), 146. 
kekayaan alam, tanpa memperhitungkan dan atau memperhatikan langgung jawab dan kewajiban sebagaimana mestinya; Ketiga, ketidakadilan muncul dalam bentuk pengalihan tanggung jawab pihak perusahaan kepada masyarakat konsumen. Mereka yang hidup dengan penghasilan rendah dan hidup dalam kemiskinan harus menanggung biaya penanganan masalah polusi yang seharusnya ditanggung oleh pihak perusahaan. ${ }^{24}$

Ketiga pokok ketidakadilan, seperti dikemukakan oleh para teolog Amerika latin diatas memperlihatkan egoisme manusia yang tanpa batas atau tak terkendali, seakan alam ini adalah musuh yang harus dimusnahkan atau dihancurkan demi kepentingan hidup manusia semata. Memang tidak rasional dan juga tidak realistis, jika sama sekali menghindari proses-proses pengelolaan lingkungan alam untuk pemenuhan kebutuhan hidup manusia. Namun yang menjadi persoalan adalah bukan pada pernyataan sikap setuju atau tidak setuju dalam pengelolaan alam untuk kepentingan manusia, melainkan yang menjadi sorotan bersama dan atau fokus kita harus disasarkan pada persoalan. Apakah ada kehidupan dan keadilan yang menuntun kita untuk mengolah atau tidak mengolah lingkungan alam untuk pemenuhan kebutuhan hidup manusia?

Ada beberapa hal yang melatari perilaku manusia yang kebablasan dalam mengelola lingkungan tanpa mempertimbangkan esensi kehidupan dan aspek keadilan bagi alam, antara lain: Pertama. Adanya prinsip superioritas berlebihan dari manusia terhadap alam. Sikap ini muncul karena klaim-klaim kebenaran yang terlampau radikal dan terkesan nai'f, bahwa hanya manusia memiliki hak istimewa untuk hidup, sementara makhluk yang lain hanya bisa hidup karena manusia. Ini sebuah pandangan yang keliru dan haras dihindari sehingga tidak mewabah bagi kehancuran keseluruhan spesies dalam planet bumi (alam semesta).

Kedua. Adanya ketidakberdayaan manusia dalam memanfaatkan teknologi buatannya sendiri dalam mengelola alam secara bertanggung jawab. Ini merupakan akibat lain dari kesombongan manusia yang selalu mengagungkan kecanggihan dan ketinggian daya produksi alatalat teknologi. Ketiga. Kecanggihan teknologi dan perkembangan peradaban atau pengetahuan manusia, yang secara tidak langsung menjadikan manusia terlampau rasional dalam setiap pengambilan keputusannya terhadap alam, tanpa dibarengi dengan nurani, atau minimal sedikit membathin, sehingga ada kesadaran terhadap pentingnya etika, moral dan spiritual religius dalam membangun sikapnya terhadap alam.

Keempat. Perkembangan ilmu pengetahuan menyebabkan manusia dengan rasio atau akalnya, secara perlahan tapi pasti, mulai menggeserkan Tuhan yang dipahami secara irasional, dan menggantikan atau menjadikan dirinya sebagai pencipta. Sejarah membuktikan, bahwa selama manusia modern mengandalkan kckuatan rasio atau ilmu pengetahuan dan teknologi sambil

${ }^{24}$ Ibid, 147.

130 | Copyright $@$ 2020, CARAKA, ISSN 2722-1407 (Cetak), 2722-1393 (Online) 
melupakan etika dan moral, maka ia akan terus berjalan menuju kehancuran, baik terhadap dirinya sendiri maupun terhadap alam lingkungan.

Kelima. Adanya kecanduan materialisme yang berlebihan. Hal ini didasarkan pada pertimbangan kebutuhan manusia semata dan mengabaikan kebutuhan dan kepentingan makMuk-makhluk yang lain. Atas dasar kepentingan dan kebutuhan manusia tanpa batas, manusia mengeruk, mengeksploitasi, memanipulasi dan memonopoli alam untuk menunjukan kemahakuasaannya terhadap alam. Keenam. Kesalahan interpretasi terhadap term-term tertentu dalam kitab suci, teristimewa soal keselamatan dan kuasa yang selalu diklaim sebagai hanya milik manusia. Dengan term-term kitab suci tersebut, secara sadar ataupun tidak, dalam keadaan yang mestinya manusia telah bersalah terhadap alam, tetapi manusia tetap memberikan pembelaannya untuk mengukuhkan kebenaran dirinya sebagai makhluk yang paling mulia, yang kepadanya diamanatkan keselamatan dan kekuasaan oleh Allah untuk menguasai alam. ${ }^{25}$

\section{Implikasi Bagi Orang Percaya Pada Masa Kini}

Dalam kehidupan masyarakat primitif dan tradisonal, manusia dan lingkungan memiliki hubungan yang bersifat kontinuitas dan seimbang. Bahkan manusia sering melihat dirinya lebih kecil, karena dia adalah gambaran atau prototipe dari dunia besar. Paham ini dianut oleh para filsuf dan penganut agama-agama kuno, termasuk agama-agama suku, yang selalu melihat dan menjaga hubungan yang harmonis anatara manusia dengan alam. Manusia berusaha menyesuaikan diri dan menyelaraskan diri dalam irama kehidupannya dengan alam, dengan cara menyesuaikan dirinya dengan musim dalam pertanian dan tidak berani mengganggu alam lingkungannya, kecuali melalui upacara ritual. ${ }^{26}$

Kenyataan menunjukan bahwa menghadapi implikasi kemajuan ilmu pengetahuan dan teknologi, manusia sepertinya dibawa masuk ke dalam sebuah rimba dilema. Bagaikan makan buah simalakama, dan atau maju kena mundur kena. Sebagian ilmuan dan teknologiwan yang serius akan mempertanyakan dan bahkan menggumuli masalah tanggung jawab mereka ketika mereka tiba pada masalah pemakaian hasil-hasil temuan sains dan teknologi. Penetapan ambang batas budaya bagi suatu produk teknologi mencerminkan sekelumit kesadaran dan keterbatasan kemampuan para ilmuan maupun teknologiwan betapa mereka sebetulnya tidak berkuasa penuh atas hasil ciptaan mereka. ${ }^{27}$ Semakin canggih penemuan ilmiah dan teknologi, semakin peka penemuan itu terhadap kemungkinan kesalahan, apabila tidak disertai sikap ekstra hati-hati pada manusia sebagai pemakai produk teknologi itu. Disinilah letak etika, moral dan spiritualitas

\footnotetext{
${ }^{25}$ Rupilu, "Teologi Alam Semesta.", 39

${ }^{26}$ Borong, Etika Bumi Baru, 21.

${ }^{27}$ Ilmu Supardan, Teknologi Dan Etika (Jakarta: BPK Gunung Mulia, 1991), 1.
} 
religius untuk menggiring nurani manusia untuk bertindak secara arif dalam menggunakan perangkat-perangkat terknologi dalam mengolah alam bagi kepentingan dan kebutuhan hidupnya.

Jujun S. Suriasumantri berpendapat, bahwa pengetahuan yang merupakan produk kegiatan berpikir manusia merupakan obor dan semen peradaban, dimana manusia menemukan dirinya dan menghayati hidup secara sempurna. ${ }^{28}$ Berbagai peralatan dikembangkan manusia untuk meningkatkan kualitas hidupnya dengan jalan menerapkan pengetahuan yang diperolehnya dengan baik dan tertanggung jawab dari segi pemanfaatan ilmu itu sendiri; selanjutnya dikatakan pula, bahwa meraka yang mendewa-dewakan ilmu sebagai satu-satunya sumber kebenaran, biasanya tidak mengetahui hakikat ilmu yang sebenarnya. Demikian juga sebaliknya dengan mereka yang memalingkan muka dari ilmu, mereka yang tidak mau melihat kenyataan betapa ilmu telah membentuk peradaban, kemungkinan besar mereka juga tidak memahami ilmu secara benar. ${ }^{29}$

Kemajuan ilmu pengetahuan klasik dan teknologi modern yang dimulai sejak zaman Francis Bacon (1561-1626) dan Rene Descartes (1595-1650), dimana hubungan antara manusia dengan alam digambarkan sebagai hubungan antara subyek dan obyek, yang kemudian melahirkan sikap eksploitatif manusia terhadap alam, menurut Jurgen Moltmann, sebagai penyebab terjadinya ketidakseimbangan proses simbiosis anlara sistem-sistem manusia dan non-manusia yang memungkinkan untuk hidup, tetapi justru manusia mendiamkan alam yang menuju kepada kematian ekologis, baik untuk alam maupun untuk manusia. ${ }^{30}$

Etika, moral dan spiritualitas religius merupakan upaya untuk menemukan asas-asas yang mendasari tindakan manusia. Tugas etika lingkungan adalah mengembangkan asas-asas berkenan dengan tindakan manusia terhadap dunia yang bukan manusia. Jadi etika lingkungan sebetulnya mempunyai tujuan praktis dan bukanlah sekedar merupakan uraian-uraian tentang tempat manusia dalam alam semesta atau pembenaran sistem etika yang disepakati diantara manusia. $^{31}$

Alkitab dan iman Kristen tidak menyangkal pentingnya ekonomi. Namun pementingan sisi ekonomi tanpa memperhatikan sisi ekologi menunjukan bahwa manusia telah melakukan tindakan salah urus atas alam yang dipercayakan kepadanya untuk dimanfaatkan dan dipelihara. Manusia cenderung memanfaatkan, tetapi tidak memelihara. Secara etis dapat dikatakan bahwa kerusakan alam berakar dalam kelalaian manusia dalam melaksanakan fungsinya secara seimbang, karena melalaikan sisi ekologi demi sisi ekonomi.

Penekanan pada sisi ekonomi ini sangat dipengaruhi oleh rasionalisme yang memandang alam sebagai obyek, lalu melahirkan materialisme. Alam dipandang sebagai

\footnotetext{
${ }^{28}$ Jujun S Suriasumantri, Ilmu Dalam Perspektif (Jakarta: Yayasan Obor Indonesia, 2001), 2.

${ }^{29}$ Ibid, 3.

${ }^{30}$ Yewangoe, Pendamaian: Suatu Studi Tentang Pemulihan Relasi Antara Allah, Manusia Dan Alam Semesta, (Jakarta: BPK Gunung Mulia, 1983), 183.

${ }^{31}$ Celia Deane Drummond, Teologi Dan Ekologi (Jakarta: BPK Gunung Mulia, 2001), 75. 132 | Copyright $@$ 2020, CARAKA, ISSN 2722-1407 (Cetak), 2722-1393 (Online)
} 
bernilai ekonomis, kurang bernilai ekologis. Artinya, alam ini bernilai untuk dipakai, tetapi kurang bernilai untuk dipelihara. Manusia hanya memandang dirinya sebagai tuan yang mempunyai hak mengambil, tetapi kurang menyadari dirinya sebagai pelayan yang berkewajiban untuk memelihara. Etika Kristen menghendaki manusia memainkan peranannya, bukan hanya, dan bahkan tidak seharusnya sebagai tuan, tetapi sebagai hamba yang melayani. ${ }^{32}$

Segi-segi ekonomi dalam bentuk materialisme yang berlebihan bagi manusia tanpa mempertimbangkan kepentingan ekonomi makhluk yang lain merupakan wujud dari karakter kehidupan manusia yang sangat antroposentris. Artinya, segala sesuatu berpusat pada manusia. Ini merupakan kekeliruan lain yang tanpa sadar dipentaskan oleh manusia di dalam dunia. Mestinya alam semesta dan segala isinya yang menjadi sentra/pusat dari segala sesuatu. Sebab tanpa kesadaran seperti ini, alam bisa dikorbankan untuk kepentingan dan kebutuhan manusia semata. Menurut pendapat umum, prinsip berpikir seperti ini merupakan hal yang wajar-wajar saja, tetapi sesungguhnya, konsep dan sikap manusia seperti ini merupakan wujud dari arogansi dan egoisme manusia yang tanpa malu dan tanpa merasa berdosa merampas hak-hak alam yang esensial. Ini bukan karakter sosok citra dan mitra Allah yang dikehendaki oleh Allah. Dalam etika solidaritas, manusia bertanggung jawab untuk sungguh-sungguh hidup dalam keharmonisan dan keserasian dengan alam. Dalam bahasa teologi etis dapat disebut hidup dalam koinonia dengan alam.

Menurut Robert P Borong, wujud implementasi dari solidaritas manusia dengan alam dapat diwujudkan dalam bentuk: pertama, Mengusahakan terciptanya lingkungan sehat, bersih dan nyaman, baik bagi sesama manusia maupun bagi makhluk alam yang lain. Kesediaan untuk memberikan kesempatan juga kepada alam untuk hidup hidup secara alamiah. Kedua, Manusia harus hidup dalam perasaan senasib-sepenanggungan dengan alam, dan menaruh rasa belaskasihan kepada alam dan unsur-unsur yang terdapat di dalamnya. Ketiga, Manusia harus membersihkan lingkungan sebagai upaya untuk membersihkan dirinya sendiri, dan menghindari dirinya dari kematian karena lingkungan yang kotor. Keempat, Manusia harus bersahabat dengan alam, agar keduanya hidup dalam keadaan hannonis dan seimbang. Kelima, mengurangi pembangunan alam buatan (artificial) karena kurang terjamin kesehatannya. ${ }^{33}$

\section{KESIMPULAN}

Adapun beberapa hal yang dapat disimpulkan dalam penulisan ini, yaitu implementasi teologi lingkungan hidup mesti nampak dalam perilaku hidup yang sehat, peduli lingkungan, menjaga dan memelihara alam serta tidak membuang sampah secara sembarangan. Konsep

\footnotetext{
32 Borong, Etika Bumi Baru, 162.

${ }^{33}$ Ibid, 167.
} 
Teologi lingkungan hidup dimplementasikan dalam bentuk-bentuk praksis yang berorientasi pada upaya menghadirkan damai Allah bagi segala makhluk. Konsep tentang Allah yang mencipta, memelihara dan menebus segala ciptaan harus disasarkan pada sikap kritis teologis terhadap realitas upaya membangun dan membingkai konsep ekklesia nula salus yang tidak relevan dengan konsep ekoteologi lingkungan hidup, dimana alam semesta dan segala isinya memiliki hak yang sama untuk memperoleh keselamatan.

\section{DAFTAR PUSTAKA}

Borong, Robert P. Etika Bumi Baru. Jakarta: BPK Gunung Mulia, 2000.

Chang, William. Moral Lingkungan Hidup. Jakarta: BPK Gunung Mulia, 2000.

Dewi Napitupulu, Nurasyah, Achmad Munandar, Sri Redjeki, and Bayong Tjasyono.

"Ecotheology Dan Ecopedagogy: Upaya Mitigasi Terhadap Eksploitasi Alam Semesta." Voice of Wesley: Jurnal Ilmiah Musik dan Agama 1, no. 2 (2018): 1-11.

Dominggus, Dicky. "Pengabdian Abdi Dalem Keraton Yogyakarta Sebagai Potret Pelayanan Masa Kini." Voice of Hami 2, no. 2 (2020): 78-93.

Drummond, Celia Deane. Teologi Dan Ekologi. Jakarta: BPK Gunung Mulia, 2001.

Jr, A G Honig. Ilmu Agama I. Jakarta: BPK Gunung Mulia, 1966.

Knitter, Paul F. Satu Bumi Banyak Agama: Dialog Multi Agama Dan Tanggung Jawab Global. Jakarta: BPK Gunung Mulia, 2003.

Nasution, S. Metode Penelitian Naturalistik Kualitatif. Bandung: Tarsito, 1996.

Newbigin, Lesslie. Injil Dalam Masyarakat Majemuk. Jakarta: BPK Gunung Mulia, 2000.

Niftrik, G C Van, and B J Bolland. Dogmatika Masa Kini. Jakarta: BPK Gunung Mulia, 1981.

Remikatu, Jefri Hina. "Teologi Ekologi: Suatu Isu Etika Menuju Eskatologi Kristen."

CARAKA: Jurnal Teologi Biblika dan Praktika 1, no. 1 (May 2020): 65-85.

Rupilu, Dave J. “Teologi Alam Semesta.” Jurnal Ilmiah Tangkoreh Putai 3, no. 1 (2007): 72.

Schumann, Olaf. Menghadapi Tangangan Memperjuangkan Kerukunan. Jakarta: BPK

Gunung Mulia, 2004.

_. Peran Kristen Dalam Perjuangan Hak-Hak Sipil/Agama-Agama Dan Perjuangan

Hak Sipil. Jakarta: Persekutuan Gereja Indonesia, 2002.

Stott, John. Isu-Isu Global: Menantang Kepemimpinan Kristen. Jakarta: Yayasan Bina Kasih OMF, 1984.

Supardan, Ilmu. Teknologi Dan Etika. Jakarta: BPK Gunung Mulia, 1991.

Suriasumantri, Jujun S. Ilmu Dalam Perspektif. Jakarta: Yayasan Obor Indonesia, 2001.

Timo, Ebenhaizer Nuban. Allah Menahan Diri, Tetapi Pantang Berdian Diri: Suatu Upaya Berdogmatika Kontekstual Di Indonesia. Jakarta: BPK Gunung Mulia, 2015.

Tjumano, Datuak. "Kerusakan Lingkungan Hidup Di Indonesia | Jurnal Intelijen."

https://jurnalintelijen.net/2018/07/03/kerusakan-lingkungan-hidup-di-indonesia/.

Widianarko, Budi. Membumikan Etika Lingkungan. Yogyakarta: Kanisius, 2011.

Yewangoe, Andreas A. Pendamaian: Suatu Studi Tentang Pemulihan Relasi Antara Allah, Manusia Dan Alam Semesta. Jakarta: BPK Gunung Mulia, 1983. 